\title{
Using Literary Work as Authentic Material for the EFL Classroom in Indonesia
}

\author{
Deri Sis Nanda, Susanto Susanto, ${ }^{a, b}$ Universitas Bandar Lampung, Indonesia
} aderisisnanda@ubl.ac.id, ${ }^{\text {bsusanto@ubl.ac.id }}$

\begin{abstract}
Literary work can be used as authentic material in the EFL classroom to achieve the language development of the learners. This study aims to discuss the role of literary texts and the benefits of using the texts for the EFL classroom. The study was conducted at the English Education Study Program, Bandar Lampung University, Indonesia. The reasons in choosing specific literary texts in the EFL classroom are evaluated and the main criteria to select the literary texts are discussed such as the motivation and the language use of the learners. It is found that the texts can facilitate the enjoyment of the learners while they are learning. The study concludes that the literary texts not only enhance the language development but also enrich the cultural representations while studying English.
\end{abstract}

Key words: Literary work, authentic material, EFL classroom.

\section{Introduction}

English has become a lingua franca, i.e. a language widely used for communication between people who do not share the same first or second language (Jenkins, 2007; Kirkpatrick, 2010; Seidlhofer, 2004). In Indonesia, a South East Asian country, English is either an additional or a core subject in schools and universities. Therefore, it has a special position in the educational curriculum. As a subject, English is taught by teachers with various teaching methods such as writing, grammar rules and translation, etc. Most English teachers have used referential materials rather than representational sources such as literary works to teach English. Literature, then, is regarded pedagogically as something separate from language (Carter \& McRae, 2004).

Moreover, literature has been considered as an authentic material that can be taught in an ESL or EFL classroom to achieve the language development of the learners (Brumfit \& Carter, 1991; Carter \& Long, 1991; Collie \& Slater, 1987; Nanda, 2016). In addition, language and literature cannot be separable because "no literature lives without language and 
International Journal of Innovation, Creativity and Change. www.ijicc.net

Volume 12, Issue 12, 2020

no language survives without literature" (Naik, 2011:1). Further, Kramsch (1993) points out that the real success of communicative approaches to language teaching lies in the ability to involve learners in the dialectic of meaning production, which can be easily provided by literary text as it is more dialogic. Therefore, as an authentic material in relation to language teaching, literary work can be exploited as a material in EFL classroom (Brumfit \& Carter, 1991; Paran, 2008). Further, as an example, Harmer (2007) adds that poetry as one of literature genres can be used in the language classroom.

\section{Literature and Language Teaching}

Literature is the expression of life in words of truth and beauty; it is the written record of man's spirit, of his thoughts, emotions, aspirations; it is the history, and the only history, of the human soul (Long, 2004). It is characterised by its artistic, its suggestive, and its permanent qualities. Literature is the record of experience interpreted by personality that behind every book there is a story which talks about a human being's eager effort to give life meaning, to create beauty, to express vivid emotions and ideas, to make men aware of themselves and the life they lead (Boas, 1931). Literature, for Lazar (1993: 19), is also "a particularly good source for developing students' abilities to infer meaning and to make interpretations". Therefore, literature has potential to be exploited as a material in the EFL classroom.

Because of the richness of meaning in literary texts, the EFL learners can actively develop to find the interpretations. The language learners are able to respond directly because literature adopts the language in real contexts. In addition, Collie and Slater (1987) throw light that literature offers a great written material covering human issues. They again say that in literature the depicted characters are from varied social background. Thus, it may enable language learners to get insights regarding the culture of people from English speaking countries (Cruz, 2010).

In the last decade, according to Irene (2015), literature has been an authentic material for teaching reading. It aims that learners can communicate actively in language classrooms. This way is closely related to the Reader-Response approach mentioned by Van (2009). For him in the approach students can have learning experience for increasing their participation and motivation. It can make the EFL classroom active. In relation to the language teaching, literary texts consist of representational language which opens up, calls upon, stimulates and uses areas of mind, from imagination to emotion, from pleasure to pain and they can create something "personal between text and reader" (McRae, 1991:3). 
International Journal of Innovation, Creativity and Change. www.ijicc.net

Volume 12, Issue 12, 2020

\section{The Role of Literature in the EFL Classroom}

For the relationship between literature and language teaching, the role of literature can be important in the EFL classroom to enrich the knowledge of both language and culture. At least, this is shown at the English Education Study Program, Bandar Lampung University (Figure 1). In its EFL classroom, literary works were used as teaching materials. With the materials, the teacher can help the students to develop their language skills (reading, listening, speaking, and writing) as well as literary skill. In addition, when using liteature as a teaching material in the classroom, the four basic language and literary skills which are taught become an integrated way such as literature with reading, writing, speaking and listening.

Figure 1. Some activities using literature in EFL classroom at the English Education Study Program, Bandar Lampung University.
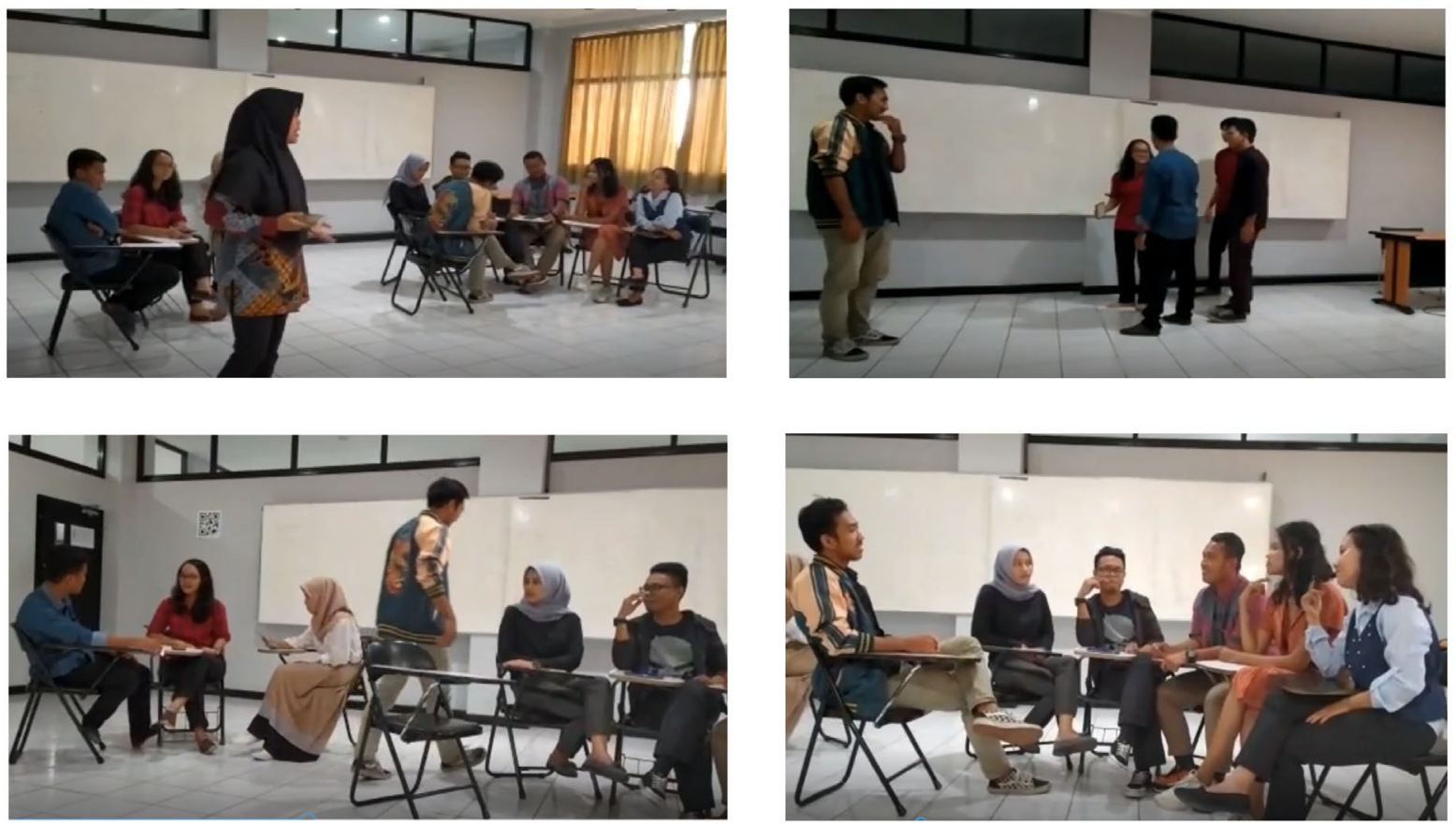

For literature with reading, as an example, the students in the English Education Study Program are given a literary text such as a poem, 'My Last Duchess' by Robert Browning (Browning, 1993). The students read the poem literally. After reading it, they are provided the questions regarding setting, speaker, listener, and plot which can be answered from the text. After answering the questions, they move to the next step, i.e. they work collaboratively to make evaluation covering the theme as well as the author's point of view. This is also a suitable time for them to share their perception and response to the cultural issues and themes. 
International Journal of Innovation, Creativity and Change. www.ijicc.net

Volume 12, Issue 12, 2020

For literature with writing, the students are taught 'My Last Duchess' to stimulate and motivate them to share their ideas in the form of writing. Because the poem talks about life during the Italian Renaissance, it offers an immense variety of themes to write on. Since the students are advanced learners, the activity which was designed for them is paraphrasing or summarising. In paraphrasing, the students are required to use their own words to rephrase the words found in the poem. The paraphrase relates to the students'effort to make sense of the poem. Although Robert Browning's 'My Last Duchess' is in a form of poetry, there is a story in it. The activity which can be used is summarising or rewriting the story. Summarising or rewriting enables the students to be aware of the variations between written and spoken English (Stern, 1991).

For literature with speaking and listening, 'My Last Duchess' can play an equally meaningful role in teaching both speaking and listening. Having students read literature aloud contributes to developing speaking as well as listening ability (Hismanoglu, 2005). Thus, asking students to read aloud can improve their pronounciation and the activity can be used for listening to English vocabulary. After reading aloud, the students move to the group activities. All of these group activities can further develop the speaking abilities of the students through pronunciation practice. Further, the pronunciation errors of the students during the act of such activities can be indicated and corrected as well.

\section{The Benefits of Literature in EFL Classroom}

Literature can help students develop interpretative abilities, increase learner's insight and bridge the cultural gap (Yeasmin, 2011). According to Zhen (2012), by using literary texts, language learners can learn about the social descriptions represented by the author. It means that literature is closely related to social culture which belongs to the author himself. For example, Robert Browning's 'My Last Duchess' talks about the Duke's wife during the Italian Renaissance or Margaret Mitchell's 'Gone with the Wind' tells of the American Civil War (Mitchell, 1996). Not only do leaners have knowledge about English language skills but also they are enriched with the social culture of English people through the author's point of view.

Although language in literary texts is relatively dynamic and flexible, the learners are exposed to various forms of language and aware of the norms of the language used. In this case, literature is diferrent from other materials for language teaching which are sometimes rigid and dull. Zhen (2012) asserts that it is in literary material that the learners can also find enjoyment to achieve language development. While the students in the English Education Study Program, Bandar Lampung University are discussing Robert Browning's 'My Last Duchess', there are benefits they can get since:

- The poem can provide with different insights towards language use; 
International Journal of Innovation, Creativity and Change. www.ijicc.net

Volume 12, Issue 12, 2020

- The poem can stimulate them to find the meaning of the vocabulary;

- The poem can evoke feeling and thought;

- The poem can make the students familiar with the cultural issues or themes based on the social contexts of the author.

Therefore, the poem 'My Last Duchess' by Robert Browning offers a good enough knowledge of the English language that the students as advanced learners can find enjoyment in and satisfy their curiosity in language development. While they are learning language they simultaneously are enriched with the culture of people from an English speaking country. Thus, Lazar (1993), states that the advantage of using poetry as literary text in teaching a foreign language can be beneficial for the students to see different uses of language in relation to vocabulary, syntax, morphology.

\section{Reasons in Choosing a Literary Text in the EFL Classroom}

Most literary texts are of great length, thus, they need consideration to choose them for use in the EFL classroom. According to Lazar (1993), in selecting a literary text as a material to teach, teachers should think of the time which is available for the students to work on the text. Because of this reason, the literary text such as the poem 'My Last Duchess' by Robert Browning is chosen as a material to be taught for the students in the English Education Study Program, Bandar Lampung University. Because it is not too long, it is considered suitable for the students. Although the poem is from the 18th century, the students can understand the language since they have earlier experience in studying literature by consulting related literary studies and through cyber literature (Nanda \& Susanto, 2020).

The other reasons why the poem 'My Last Duchess' is selected as the authentic material are provided below:

- The poem provides material in developing language skills;

- The poem can supply interesting subjects that link to the students' ideas and interpretations;

- The poem can be used in many language based activities such as practising reading aloud, summarising and paraphrasing;

- The poem shows the universal issues and themes that can be discussed in the class;

- The poem motivates the students to give their opinion through dialogue.

\section{Criteria in Selecting a Literary Text in the EFL Classroom}

Selecting a suitable literary text for use in the EFL classroom becomes an important thing that should be done by teachers. Criteria in selecting a literary text for EFL classroom are based on students' motivation, as well as their language level (Lazar, 1993; Collie \& Slater, 
International Journal of Innovation, Creativity and Change. www.ijicc.net

Volume 12, Issue 12, 2020

1987; Hismanoglu, 2005). For students' motivation, a selected text should motivate the learners to discuss the themes and universal issues delivered by the author. Irene (2015) states that a literary text which is selected should have strong power to motivate the students to read as well as to interpret the meaning.

For students' language level, "as a general rule, it is better to choose for teaching literary texts which are not too far beyond the students' normal reading comprehension" (Carter \& Long, 1991: 5). Therefore, it is necessary to select a literary text which is based on students' language proficiency so it can give enjoyment to students while they are reading. In relation to criteria in selecting a literary text in the EFL classroom, Robert Browning's 'My Last Duchess' is a suitable text to be taught to students in the English Education Study Program, Bandar Lampung University. The language of the poem is not far from their language level. As the poem tells the story of a few people in the specific time period the students are motivated to explore the themes, settings and characters. The poem also stimulates them to paraphrase the content of the poem.

\section{Conclusion}

In conclusion, using literary work as authentic material has an important role in the EFL classroom which is exemplified in the English Education Study Program, Bandar Lampung University. Thus, literary texts can be utilised to facilitate language teaching and learning. Literary texts help the students to learn the language in context. As the example, the poem 'My Last Duchess' as used in the EFL classroom can motivate them to do various language based activities. Also, it can stimulate the students to find the surface meaning and the underlying meaning in the poem. The universal issues discussed in the poem broaden the knowledge of the students regarding to the cultural enrichment. Finally, for the teachers, teaching English through literature in EFL classroom can enrich the experience. The learners gain not only language skill - reading, speaking, listening, and writing but also literary skill the skills of paraphrasing, summarising and interpreting. For further research, it can be studied how literary work as authentic material can be used for teaching students with disabilities, such as visual impairment (Jenks, 2005; Susanto \& Nanda, 2018), for improving students' academic literacy (Mukhroji, 2020), and for developing other teaching strategies to face students' learning problems in EFL classroom (Alquraishy, Sagban, \& AlMumar, 2020; Huwari, 2019). 
International Journal of Innovation, Creativity and Change. www.ijicc.net

Volume 12, Issue 12, 2020

\section{REFERENCES}

Alquraishy, S. W., Sagban, A. A., \& AlMumar, H. A. (2020). The Role of Cubing Strategy in Improving Iraqi EFL Intermediate Learners' Reading Comprehension and Attitude. International Journal of Innovation, Creativity and Change, 11(6), 339-352.

Boas, R. P. (1931). The Study and Interpretation of Literature. Harcourt: Brace and Company Inc.

Browning, R. (1993). My Last Duchess and Other Poems. New York: Dover Publications, Inc.

Brumfit, C. J. and Carter, R. A. (1991). Literature and Language Teaching. Oxford: Oxford University Press.

Carter, R. and Long, M. (eds). (1991). Teaching Literature. London: Longman.

Carter, R and McRae, J. (2004). Language, Literature, and the Learner: Creative Classroom Practice. England: Routledge.

Collie, J. and Slater, S. (eds). (1987). Literature in the Language Classroom. Cambridge: Cambridge University Press.

Cruz, J. H. R. (2010). The Role of Literature and Culture in English Language Teaching. Linguistica, 7, 1-16.

Harmer, J. (2007). The Practice of English Language Teaching. London: Pearson Education Limited.

Hismanoglu, M. (2005). Teaching English through Literature. Journal of Language and Linguistic Studies, 1(1), 53-66.

Huwari, I. F. (2019). Problems Faced by Jordanian Undergraduate Students in Speaking English. International Journal of Innovation, Creativity and Change, 8(9), 203-217.

Irene, K. V. (2015). The Use of Literature in the Language Classroom: Methods and Aims. International Journal of Information and Education Technology, 5(1), 74-79.

Jenkins, J. (2007). English as a lingua franca: Attitude and identity. Oxford: Oxford University Press.

Jenks, E. B. (2005). Parents' stories of raising children with visual impairments in a sighted world. Journal of Contemporary Ethnography, 34, 143-169.

Kirkpatrick, A. (2010). English as a Lingua Franca in ASEAN: A multilingual model. Hong Kong: Hong Kong University Press.

Kramsch, C. (1993) Context and Culture in Language Teaching. Oxford: Oxford University Press. 
International Journal of Innovation, Creativity and Change. www.ijicc.net Volume 12, Issue 12, 2020

Lazar, G. (1993) Literature and Language Teaching: A Guide for Teachers and Trainers. Cambridge: Cambridge University Press.

Long, W. J. (2004). English Literature: its History and its Significance for the life of English Speaking World. Gutenberg: The Project Gutenberg EBook.

McRae, J. (1991). Literature with a Small 'I'. London: Macmillan Publishers Ltd.

Mitchell, M. (1996). Gone with the Wind. New York: Pocket Book.

Mukhroji, M. (2020). Exploring the Academic Writing Needs to Improve the Academic Literacy of the Indonesian EFL Undergraduate and Masters Students. International Journal of Innovation, Creativity and Change, 10(10), 252-269.

Naik, N. S. (2011). Teaching English Language through Literature. New Delhi: Sarup Book Publishers PvT.Ltd.

Nanda, D. S. (2016, May). Fostering the Use of Drama for English Language Learners in the EFL Classroom. In International Conference on Education and Language (ICEL) (p. 7).

Nanda, Deri S., and Susanto Susanto. "The Emergence of Cyber Literature: A challenge to Teach Literature from Text to Hypertext.” EdArXiv, 21 Jan. 2020. Web.

Paran, A. (2008). The role of literature in instructed foreign language learning and teaching: An evidence-based survey. Language Teaching, 41(4), 465-496.

Seidlhofer, B. (2004). Research perspectives on teaching English as a lingua franca. Annual Review of Applied Linguistics, 24, 209-239.

Stern, S. (1991). An Integrated Approach to Literature in ESL/EFL. In Murcia, M. (ed.). Teaching English as a Second or Foreign Language (328-346). Boston: Heinle \& Heinle Publishers.

Susanto, S., \& Nanda, D. S. (2018). Teaching and learning English for visually impaired students: an ethnographic case study. English Review: Journal of English Education, 7(1), 83-92.

Van, T. T. M. (2009). The relevance of literary analysis to teaching literature in the EFL classroom. English Teaching Forum, 3, 2-9.

Yeasmin, N. et.al. (2011). Teaching Language through Literature: Designing Appropriate Classroom Activities. ASA University Review, 5(2), 283-297.

Zhen, C. (2012). Characteristics and Strategies of Literature Teaching in the EFL Context in China. International Journal of Electronics and Communication Engineering, 5(3), 3543. 